nearing completion. More than $\mathbf{1 5 2 0}$ was spent purchasing and transporting animals like penguins, sea-lion, wolves, wallabies and laughing jackass; but owing to various restrictions some valuable animals offered could not be accepted. The meeting was followed by a lecture by Father P. J. Kennedy, a well-known local ornithologist, on the birds of Phœnix Park. Father Kennedy gave a detailed history of the formation of the Park until it was turned into a bird sanctuary in 1937, its trees, shrubs, lakes and ponds being so valuable. The birds he then discussed were the 83 species which have been observed in the Park, and included grey crow, rook, jackdaw, magpie, jay, starling, greenfinch, goldfinch (which he said is increasing), chaffinch, bullfinch, linnet, crossbill, yellow-hammer, skylark, pied wagtail, tree-creeper, black-cap and spotted fly-catcher.

\section{The Maidenhair Tree}

THE origin of the curious generic name, Ginkgo biloba, of this tree is very fully discussed, with reference to original Chinese and Japanese descriptions, by Prof. A. C. Moule in T'Oung Pao, 23, published by the firm of E.J. Brill, Leyden. The name seems to be due to Engelbert Kaempfer, a German naturalist (1651-1716) who was in Japan apparently about 1690-2. The Kaempfer MSS. are stated by Larousse to be preserved in the Museum of Botany at Leyden where, however, search has failed to find them; Prof. Moule, however, through Sir Albert Seward, has traced the original entries of Kaempfer in his manuscripts in the British Museum. These seem to make it clear that when Kaempfer, some eighteen years later, published the names from his original descriptions, he deciphered incorrectly an original manuscript entry of Sankyo in the form of Ginkgo, where it is difficult to decide whether the ' $g$ ' is a slip in transcription or a misprint that has been overlooked. Thus "this strange word, which is unpronounceable and probably ought never to have existed, has been for nearly two centuries and, I suppose, will always be the generic name of this beautiful and interesting tree". There is a very full discussion of the numerous Chinese names of this tree which are all either descriptive names of two or more words or are frankly borrowed from other trees, suggesting that the tree was not known in northern China during the centuries when the Chinese classical civilization and language were being formed. This may confirm the view of $F$. N. Meyer and others that the tree is indigenous in the forests of Chê-Chiang, but in favour of the other view that it survives only in cultivation is the fact that no large specimens have been reported from forests. There is an interesting discussion of its fire-resisting qualities, which were exemplified by the recovery of many trees in Tokyo after the big fire that followed the earthquake in 1923 ; popular testimony thus made a huge Ginkgo tree largely responsible for the survival of the great temple of Kwannon at Asakasa; it was believed that the tree literally rained moisture on the roof, and also protected it against burning fragments carried in the wind.

\section{Health Committee of the League of Nations}

Ar the twenty-fifth session of the Health Committee of the League of Nations, April 26-May 1 (G. Allen and Unwin, League of Nations Department, 40 Museum St., Iondon, W.C.I : Report to the Council on the Work of the 25th Session of the Health Committee, 1s.) the next three-year programme was discussed and approved. Among the permanent activities of the Committee, its work on biological standards is far from being completed. New therapeutic agents gain acceptance with the advance of science and require assay in terms of some common standard, and other standards already adopted are either open to improvement or, being composite, are liable to be replaced sooner or later by the active substance in pure form, apart from the possibility of physical or chemical methods replacing the biological method. Forty-one countries have adopted or are about to adopt the international standards recommended by the Permanent Com. mission on Biological Standards, and thirty-one Governments have established or are about to establish national centres, thus simplifying the task of the central institutes at Copenhagen and Hamp. stead. For drugs like digitalis, pituitary extract and arsphenamine, no insuperable difficulties are anticipated in preparing national standards, but it is expected that for serological standards the Copenhagen Institute will have to continue to supply international standard sera to most of the national centres. The standardization of anti-anthrax serum, examined in 1925, requires further investigation in collaboration with the Institute at Budapest and Bucharest. Further study of the standardization of anti-swineerysipelas serum is also necessary as well as con. sideration of changes in the international standards for tuberculin and staphylococcus anti-toxin. The standardization of anti-snake venom sera, pharmacological standards, as well as those for vitamins and sex hormones, also fall within the next three-year programme of the Commission. Other matters in the programme of the Committee are leprosy, rural hygiene, housing, physical education, nutrition and opium and other dangerous drugs.

\section{Dietetics and Social Problems}

THE problem to what extent a wise social policy, taking into account modern scientific developments in the field of nutrition, can help to raise the standard of living in certain countries, or for certain categories of population, which at present suffer from undernourishment or malnutrition, is being investigated by the International Labour Office, assisted by a Committee of Experts which met at Geneva on April 9-10, under the chairmanship of Mr. Bramsnaes. This committee discussed the efforts of the International Labour Office to demonstrate the progress of dietetic science and its importance in regard to social questions. Special stress was laid on the necessity of distinguishing between the physiological, health and social aspects of the problem, and it was agreed that the studies should be studied simultaneously in various countries according to a uniform 